\title{
PENGARUH PERBEDAAN KOMPOSISI LIMBAH AMPAS TAHU TERHADAP PERTUMBUHAN TANAMAN PAK CHOI (Brassica rapa L. ssp. chinensis)
}

\author{
Widya Rahmina ${ }^{\text {() }}$, Ilah Nurlaelah ${ }^{2)}$, Handayani ${ }^{3)}$ \\ ${ }^{1}$ Program Studi Pendidikan Biologi FKIP, Universitas Kuningan \\ ${ }^{2}$ Program Studi Pendidikan Biologi FKIP, Universitas Kuningan \\ Email: Ilah_uniku@yahoo.co.id \\ ${ }^{3}$ Program Studi Pendidikan Biologi FKIP, Universitas Kuningan \\ Email: handa_yani08@yahoo.co.id
}

APA Citation: Rahmina, W., Nurlaelah, I., \& Handayani, H. (2017). Pengaruh Perbedaan Komposisi Limbah Ampas Tahu Terhadap Pertumbuhan Tanaman Pak Choi (Brassica Rapa L. Ssp. Chinensis). Quagga: Jurnal Pendidikan dan Biologi, 9(2), 32-38. doi: 10.25134/quagga.v9i02.746.

\begin{abstract}
Abstrak: Limbah ampas tahu dapat menyebabkan pencemaran lingkungan. Selama ini limbah ampas tahu kurang dimanfaatkan secara maksimal. Padahal, limbah ampas tahu memiliki kandungan protein yang cukup tinggi serta senyawa-senyawa yang berpotensi untuk meningkatkan kesuburan tanah dan tanaman. Penelitian ini bertujuan untuk mengetahui pertumbuhan tanaman pak choi dengan menggunakan variasi komposisi limbah ampas tahu serta untuk mengetahui kandungan NPK yang terdapat dalam limbah ampas tahu. Penelitian ini menggunakan Rancangan Acak Lengkap (RAL) dengan komposisi limbah ampas tahu masing-masing 25\%, 50\%, 75\% dan 100\%. Kontrol positif pupuk kandang dan kontrol negatif tanah. Parameter yang diukur pada tanaman pak choi, yaitu jumlah daun dan berat basah tanaman. Analisis data diperoleh dengan menggunakan uji Analisis Varians dan dilanjut dengan uji Beda Nyata Terkecil (BNT) untuk parameter jumlah daun sedangkan uji Wilayah Berganda Duncan (DMRT) digunakan untuk parameter berat basah. Berdasarkan uji statistik yang telah dilakukan menggunakan uji BNT untuk jumlah daun dan uji DMRT untuk berat basah menunjukan bahwa ada perbedaan yang signifikan diantara variasi komposisi limbah ampas tahu, dalam hal ini komposisi limbah ampas tahu 100\% yang paling efektif dalam mempengaruhi pertumbuhan tanaman pak choi. Hasil penelitian menunjukan kandungan unsur N,P,K limbah ampas tahu kering ditinjau dari kriteria unsur $N$ tercatat rendah, yaitu 0,110\% sedangkan unsur P dan unsur K tercatat sangat tinggi, yaitu 1,219\% dan 0,361\%. Kata Kunci :Limbah Ampas Tahu, Brassica rapa L. ssp. Chinensis
\end{abstract}

Abstract: Tofu waste can cause environmental pollution. So far, tofu waste has not been fully utilized. In fact, tofu waste has a high protein content and compounds that have the potential to increase soil and plant fertility. This study aims to determine the growth of pak choi plants by using variations in the composition of tofu waste and to determine the NPK content found in tofu waste. This study used a Completely Randomized Design (CRD) with the composition of tofu waste each 25\%,50\%, 75\% and 100\%. Positive control of manure and negative control of soil. The parameters measured in the pak choi plant are the number of leaves and the wet weight of the plant. Data analysis was obtained using the Variance Analysis test and continued with the Smallest Significant Difference test (LSD) for leaf number parameters while the Duncan Multiple Area test (DMRT) was used for wet weight parameters. Based on statistical tests that have been carried out using the LSD test for the number of leaves and DMRT test for wet weight shows that there is a significant difference between the variation of tofu waste composition, in this case the composition of $100 \%$ tofu waste is most effective in influencing the growth of pak choi plants. The results showed that the content of $N, P, K$ dry tofu waste in terms of the N element criteria was recorded as low, which was $0.110 \%$ while the P element and K elements were very high, namely $1.219 \%$ and $0.361 \%$.

Keywords: Tofu Waste, Brassica rapa L. ssp. chinensis

\section{PENDAHULUAN}

Tahu merupakan salah satu makanan favorit yang dikonsumsi masyarakat indonesia. Tingginya konsumsi masyarakat terhadap tahu menyebabkan banyak industri tahu yang berkembang. Tahu kuningan sudah memiliki pamor tersendiri dikalangan masyarakat yang singgah di kuningan. Industri tahu yang berkembang di kuningan mulai dari yang berskala kecil hingga menengah ke atas. Menurut Nurhayati et al (2011) kabupaten kuningan pada tahun 2009 memiliki industri tahu mencapai 67 unit yang tersebar dibeberapa kecamatan.

Berdasarkan hasil observasi pabrik tahu didaerah Ciawigebang, beberapa pabrik tahu tersebut tidak memiliki bagian khusus untuk 
menangani limbah yang dihasilkan. Limbah padat yang berupa ampas tahu biasanya hanya dimanfaatkan untuk pakan ternak. Menurut Suswardany et al (2006) sebagian besar industri tahu memanfaatkan ampas tahunya untuk pakan ternak, sebagian dijual untuk membuat tempe gembus dan sisanya dibuang di pekarangan. Ampas tahu yang dibuang di pekarangan dapat mencemari lingkungan yang ada disekitarnya karena bau yang dihasilkan dari proses dekomposisi. Salah satu upaya dalam mengatasi hal tersebut adalah dengan memanfaatkan limbah sebagai bahan alternatif untuk memproduksi pupuk. Limbah yang dapat dimanfaatkan sebagai pupuk salah satunya adalah limbah tahu.

Menurut Tua et al (2014) keuntungan menggunakan ampas tahu sebagai pupuk adalah karena ampas tahu banyak tersedia dan memiliki kandungan protein yang cukup tinggi. Menurut Anggoro (dalam Tua et al, 2014) ampas tahu mengandung protein $43,8 \%$, lemak $0,9 \%$, serat kasar $6 \%$, kalsium $0,32 \%$, fosfor $0,76 \%$, magnesium $32,3 \mathrm{mg} / \mathrm{kg}$ dan bahan lainnya. Menurut Tillman (dalam Tua et al, 2014) menyatakan ampas tahu mengandung $\mathrm{N}$ (Nitrogen) rata-rata $16 \%$ dari protein yang dikandungnya.

Menurut Ali et al (2008) menyatakan bahwa ampas tahu memiliki kandungan protein yang lebih tinggi dibandingkan dengan limbah cairnya. Ampas tahu banyak mengandung senyawa-senyawa anorganik yang dibutuhkan oleh tanaman, seperti senyawa-senyawa Phosfor (P), Besi (Fe) serta Kalsium (Ca). Menurut Anonim (dalam Hasibuan 2015) limbah tahu mengandung Nitrogen $(\mathrm{N})$, Phospor $(\mathrm{P})$, Kalium $(\mathrm{K})$, Calsium (Ca), Magnesium ( $\mathrm{Mg})$, dan Karbon (C) organik yang berpotensi untuk meningkatkan kesuburan tanah. Berdasarkan analisis bahan kering ampas tahu mengandung kadar air 2,69\%, protein kasar $27,09 \%$, serat kasar 22,85\%, lemak $7,37 \%$, abu $35,02 \%$, bahan ekstrak tanpa nitrogen (BETN) 6,87\%, kalsium $0,5 \%$, dan fosfor $0,2 \%$. Kandungan-kandungan tersebut memiliki potensi untuk dapat meningkatkan kesuburan tanah dan tanaman. Berdasarkan kandungan unsur hara tersebut menurut Asmoro et al (2008) limbah ampas tahu dapat digunakan sebagai pupuk organik pada tanaman sayuran. Oleh karena itu, limbah ampas tahu dapat digunakan sebagai alternatif pupuk bagi tanaman berdasarkan kandungan yang terdapat didalamnya.

Pak choi adalah salah satu tanaman yang termasuk dalam famili Brassiceae dan cukup menjanjikan untuk dibudidayakan. Menurut Rubatzky and Yamaguchi (1998) sayuran ini termasuk jenis sayuran dengan umur pendek kurang lebih 40 hari dengan tinggi $15-30 \mathrm{~cm}$, sehingga dapat dipanen dengan cepat. Pak choi kurang peka terhadap suhu dibandingkan sawi putih dan karena itu memiliki adaptasi yang lebih luas. Sayuran ini adalah jenis tanaman yang dapat tumbuh baik di dataran rendah maupun tinggi, namun biasanya pak choi ditanam di dataran tinggi.

Menurut Tay dan Toxopeus (dalam Maryam, 2009) pak choi membutuhkan 10-20 ton/ha pupuk kandang, 55-75 kg N/ha, 40-80 P/ha dan 80-110 K/ha saat tanam. Produktivitas dapat mencapai 10-20 ton/ha untuk kultivar dengan ukuran kecil dan 20-30 ton/ha untuk kultivar dengan ukuran besar. Berdasarkan kebutuhan pupuk pada tanaman pak choi, limbah ampas tahu dapat digunakan sebagai alternatif pupuk organik bagi tanaman pak choi (Brassica rapa $L$. ssp Chinensis).

Selain memanfaatkan limbah dengan mengubahnya menjadi pupuk yang bermanfaat, penelitian ini membantu mengembangkan life skill bioentrepreneur mahasiswa. Menurut Agustina (2015) bioentrepreneurship adalah proses mengidentifikasi, mengembangkan, dan membawa visi ke dalam kehidupan. Sehingga dapat dikatakan bahwa bioentrepreneur merupakan kewirausahaan yang dikembangkan menggunakan konsep-konsep biologi.

Penelitian ini dilakukan dengan maksud untuk mengetahui pertumbuhan tanaman pak choi (Brassica rapa L. ssp Chinensis) dengan penggunaan variasi komposisi limbah ampas tahu. Tujuan dari penelitian ini antara lain: (1) Mengetahui pertumbuhan tanaman pak choi (Brassica rapa L. ssp Chinensis) dengan menggunakan variasi komposisi limbah ampas tahu. (2) Mengetahui kandungan NPK yang terdapat dalam limbah ampas tahu.

\section{METODOLOGI PENELITIAN \\ Tempat dan Waktu}

Percobaan ini dilaksanakan di Laboratorium Fakultas Keguruan dan Ilmu Pendidikan serta Laboratorium Green House Fakultas Kehutanan Universitas Kuningan, Alamat: Jl. Cut Nyak Dien No. 36 A Cijoho Kuningan. Percobaan dilaksanakan pada bulan Maret 2016 sampai bulan Mei 2016.

\section{Bahan dan Alat}

Bahan yang digunakan dalam penelitian ini adalah benih Pak Choi (Brassica rapa L. ssp. 
chinensis), ampas tahu kering sebanyak $4 \mathrm{~kg}$, EM4 1 liter, gula merah $1 / 4 \mathrm{~kg}$, bokashi dopilet 1 $\mathrm{kg}$, dedak $1 \mathrm{~kg}$, kotoran kambing kering $6 \mathrm{~kg}$, tanah kebun dan air sumur secukupnya.

Alat yang digunakan adalah box pengomposan serta tutup box pengomposan, baskom yang berdiameter $30 \mathrm{~cm}$, sendok kayu, trash bag ukuran $50 \times 75 \mathrm{~cm}$, termometer air raksa, sensiglove, surgical face mask, polybag ukuran 25 x $25 \mathrm{~cm}$, nampan ukuran 30 x 19 × 20 $\mathrm{cm}$, plastik es ukuran $4,5 \times 20 \mathrm{~cm}$, sprayer, Neraca digital, Neraca dan alat tulis.

\section{Metode Penelitian}

Penelitian ini menggunakan Rancangan Acak Lengkap (RAL) yaitu komposisi kompos limbah ampas tahu yang terdiri dari 6 perlakuan. Perlakuan tersebut diulang sebanyak 4 kali sehingga terdapat 24 unit percobaan. Jumlah keseluruhan bibit pak choi yang digunakan adalah 48 bibit, dimana tiap unit percobaan terdiri dari 2 bibit yang langsung dijadikan sampel.

Adapun komposisi limbah ampas tahu yang diberikan sebagai perlakuan adalah sebagai berikut :

A = Komposisi Kompos ampas tahu sebanyak $25 \%$ (50 gram)

$\mathrm{B}=$ Komposisi Kompos ampas tahu sebanyak $50 \%$ (100 gram)

$\mathrm{C}=$ Komposisi Kompos ampas tahu sebanyak $75 \%$ (150 gram)

$\mathrm{D}=$ Komposisi Kompos ampas tahu sebanyak $100 \%$ (200 gram)

Kontrol positif $(\mathrm{P})=$ Pupuk Kandang (500 gram) Kontrol negatif $(\mathrm{N})=$ Tanah $(1000$ gram $)$

Data yang diperoleh dianalisis secara statistik menggunakan Analisis Sidik Ragam dilanjutkan dengan uji Beda Nyata Terkecil (BNT) untuk jumlah daun dan uji Berganda Duncan (Duncan's Multiple Range Test) untuk berat basah pada taraf 5\%.

\section{Parameter Pengamatan}

Jumlah daun (helai) dan berat basah (gram) tanaman pak choi.

\section{HASIL DAN PEMBAHASAN \\ Pembuatan Kompos Limbah Ampas Tahu}

Berdasarkan pengukuran suhu pada saat pengomposan rata-rata peningkatan suhu pada bak 1 adalah $30,2^{\circ} \mathrm{C}$ sedangkan rata-rata peningkatan suhu bak 2 adalah $29,8^{\circ} \mathrm{C}$. Banyaknya tumpukan pada kompos dapat meningkatan temperatur kompos limbah ampas tahu sehingga dapat mempengaruhi kecepatan proses pengomposan. Pada temperatur suhu bak 1 penurunan suhu mendekati suhu awal pengomposan lebih cepat dibandingkan dengan penurunan suhu pada bak 2 .

Temperatur maksimum yang dicapai pada kompos limbah ampas tahu bak 1 dan bak 2 secara berurutan adalah $34,2^{\circ} \mathrm{C}$ dan $33,8^{\circ} \mathrm{C}$. Pada proses pengomposan, faktor suhu sangat berpengaruh terhadap jenis mikroorganisme yang terlibat didalamnya. Pembuatan kompos yang berbahan dasar limbah ampas tahu dengan penambahan EM4 sebagai aktivator ini merupakan proses pengomposan yang cenderung anaerob. Menurut Yuwono (2006: 77) suhu optimum untuk pengomposan anaerobik adalah $35-45^{\circ} \mathrm{C}$.

Kematangan kompos ditandai dengan warna coklat kehitaman, tidak berbau, dan penurunan suhu sampai sekitar suhu pengomposan.

\section{Pertambahan Jumlah Daun (Helai)}

Hasil analisis sidik ragam menunjukan bahwa pemberian limbah ampas tahu berpengaruh nyata terhadap pertambahan jumlah daun. Hasil uji lanjut BNT pada taraf 5\% disajikan pada tabel 1 .

Tabel 1. Hasil uji BNT terhadap Jumlah Daun Tanaman Pak Choi

\begin{tabular}{|c|c|c|c|c|c|c|c|c|}
\hline \multirow[b]{2}{*}{ Perlakuan } & & A & $\mathrm{C}$ & $\mathbf{N}$ & B & $P$ & D & \multirow[b]{2}{*}{ Notasi } \\
\hline & $\begin{array}{c}\text { Rata- } \\
\text { rata }\end{array}$ & 7,33 & 8,33 & 8,78 & 9,05 & 9,23 & 11,25 & \\
\hline D & 11,25 & $3,92 * *$ & $2,92 * *$ & $2,47^{* *}$ & $2,2 * *$ & $2,02^{* * *}$ & - & $\mathrm{c}$ \\
\hline $\mathbf{P}$ & 9,23 & $1,9 * *$ & 0,9 & 0,45 & 0,18 & - & & $\mathrm{b}$ \\
\hline B & 9,05 & $1,72 * *$ & 0,72 & 0,27 & - & & & $\mathrm{b}$ \\
\hline $\mathbf{N}$ & 8,78 & $1,45^{* *}$ & 0,45 & - & & & & $\mathrm{b}$ \\
\hline $\mathrm{C}$ & 8,33 & $1 * *$ & - & & & & & $\mathrm{b}$ \\
\hline A & 7,33 & - & & & & & & a \\
\hline
\end{tabular}

Berdasarkan tabel 1. di atas dapat dilihat bahwa pertambahan jumlah daun tanaman pak choi terjadi peningkatan rata-rata jumlah daun dari komposisi $25 \%, 50 \%, 75 \%, 100 \%$, perlakuan kontrol positif dan negatif secara berturut-turut 7,$33 ; 9,05 ; 8,33 ; 11,25 ;$ dan 9,$23 ; 8,78$. Rata-rata jumlah daun tanaman pak choi yang tertinggi terdapat pada perlakuan D (100\% limbah ampas tahu) sebesar 11,25. Sedangkan rata-rata jumlah daun yang terendah pada perlakuan A $(25 \%$ limbah ampas tahu) sebesar 7,33. Jumlah daun pada perlakuan D (100\% limbah ampas tahu) dengan konsentrasi kontrol menunjukan perbedaan yang signifikan.

Berat Basah (Gram)

Hasil analisis sidik ragam menunjukan bahwa pemberian limbah ampas tahu 
berpengaruh nyata terhadap berat basah tanaman pak choi. Hasil uji lanjut DMRT pada taraf 5\% disajikan pada tabel 2.

Tabel 2. Hasil uji DMRT terhadap Berat Basah Tanaman Pak Choi

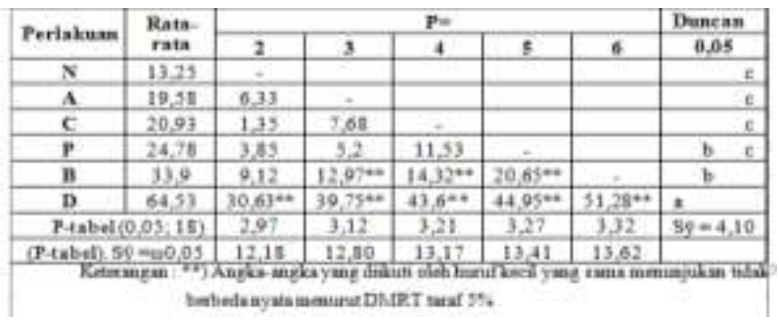

Berdasarkan tabel 2. di atas dapat dilihat bahwa berat basah tanaman pak choi terjadi peningkatan rata-rata berat basah dari komposisi $25 \%, 50 \%, 75 \%, 100 \%$, perlakuan kontrol positif dan negatif secara berturut-turut 19,58; 33,9; 20,$93 ; 64,53$; dan 24,$78 ; 13,25$. Rata-rata berat basah tanaman pak choi yang tertinggi terdapat pada perlakuan D (100\% limbah ampas tahu) sebesar 64,53. Sedangkan rata-rata berat basah yang terendah pada perlakuan N (Kontrol Negatif) sebesar 13,25. Berat Basah pada perlakuan D (100\% limbah ampas tahu) menunjukan perbedaan yang signifikan dengan perlakuan lainnya.

Kandungan Nitrogen (N), Fosfor (P) dan Kalium (K) pada Limbah Ampas Tahu

Berdasarkan hasil uji analisis kandungan unsur hara NPK pada limbah ampas tahu didapatkan data sebagai berikut (Tabel 3.)

Tabel 3. Hasil analisis kandungan unsur hara NPK pada Limbah Ampas Tahu

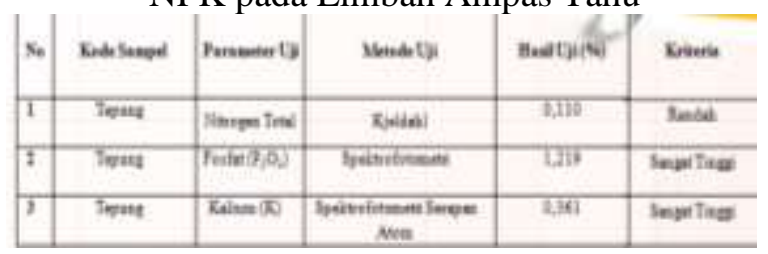

Dari tabel 3. Diatas didapat data bahwa kandungan unsur NPK yang rendah menurut Harjowigeno (dalam Surtinah, 2013) terdapat pada unsur $\mathrm{N}$ dengan nilai $0,110 \%$. Unsur $\mathrm{P}$ dan $\mathrm{K}$ dengan nilai $1,219 \%$ dan $0,361 \%$ yang artinya unsur hara tersebut bernilai sangat tinggi.

Proses pengomposan membutuhkan waktu selama 34 hari. Semua bahan sudah siap, ampas tahu, bokashi dopilet dan dedak dicampurkan secara merata serta disiram atau disemprot dengan larutan A (larutan gula merah) dan larutan B (hasil pencampuran larutan EM4 dengan air) secara merata. Pada saat temperatur kompos mulai turun dan kompos sudah matang bau tersebut tidak ada. Menurut Suwahyono dkk (2015: 32) Effective Microoganism 4 tidak hanya mempercepat proses pengomposan tetapi juga dapat menghilangkan bau yang timbul selama proses pengomposan. Hal ini sesuai dengan kompos yang dihasilkan dari pencampuran EM4 dimana kompos yang matang tidak berbau.

Kenaikan suhu yang terjadi ditimbulkan akibat aktivitas mikroorganisme yang terdapat didalam bahan kompos limbah ampas tahu. Aktivitas mikroorganisme yang terjadi berupa aktivitas metabolisme dimana senyawa kompleks akan dirombak menjadi senyawa yang lebih sederhana. Aktivitas metabolisme ini akan menghasilkan panas sehingga menyebabkan temperatur meningkat. Pada tahap ini pula, mikroorganisme memperbanyak diri dengan cepat. Pada proses pengomposan terjadi proses perombakan bahan organik (metabolisme) yang menghasilkan energi. Energi yang dihasilkan inilah yang menyebabkan suhu meningkat. Hal ini serupa dialami oleh Nan Djuarnani (dalam Ali et al, 2008) dimana peningkatan suhu yang terjadi pada awal pengomposan ini disebabkan oleh panas yang dihasilkan dari perombakan bahan organik oleh mikroorganisme.

Berdasarkan hasil perhitungan jumlah daun yang teramati bahwa rata-rata pertambahan jumlah daun perlakuan A paling rendah dibandingkan perlakuan yang lainnya dan perlakuan $\mathrm{D}$ memiliki rata-rata pertambahan daun paling tinggi dibandingkan dengan perlakuan yang lainnya. Kecukupan unsur hara bagi pertumbuhan tanaman sangat berpengaruh. Unsur hara yang cukup bagi pertumbuhan tanaman dapat membuat tanaman tumbuh dengan optimal. Sedangkan tanaman yang kekurangan unsur hara akan menyebabkan tanaman tersebut tidak dapat tumbuh secara optimal. Meskipun kandungan unsur $\mathrm{N}$ yang terdapat pada limbah ampas tahu berada pada kriteria rendah namun dikarenakan komposisi kompos limbah ampas tahu pada perlakuan D lebih banyak dibandingkan perlakuan lainnya menyebabkan pertambahan jumlah daun pada perlakuan D lebih baik dibanding perlakuan lainnya. Menurut Hardjadi (dalam Harahap et al, 2015) Unsur N meningkatkan fotosintesa dan hasilnya dapat diakumulasikan pada seluruh bagian tanaman untuk pertumbuhan, termasuk untuk pembentukan daun. Sehingga dapat dikatakan bahwa banyaknya komposisi unsur $\mathrm{N}$ pada kompos limbah ampas tahu yang digunakan 
berpengaruh terhadap pertambahan jumlah daun pada tanaman pak choi terutama kompos pada perlakuan D yang komposisinya lebih banyak. Menurut Lakitan (dalam Harahap et al, 2015) pertumbuhan dan perkembangan daun dipengaruhi oleh faktor genetik dan faktor lingkungan.

Semakin tinggi komposisi kompos ampas tahu yang diberikan menyebabkan pertambahan jumlah daun semakin meningkat. Peningkatan tersebut disebabkan pemberian kompos ampas tahu mampu menyediakan unsur hara yang dibutuhkan oleh tanaman pak choi sehingga mendorong pertumbuhan vegetatif tanaman antara lain pertambahan jumlah daun. Perlakuan D (100\% limbah ampas tahu) mempunyai kandungan unsur hara yang lebih banyak dibandingkan perlakuan yang lainnya.

Berdasarkan hasil perhitungan berat basah yang teramati bahwa rata-rata berat basah perlakuan $\mathrm{N}$ paling rendah dibandingkan perlakuan yang lainnya dan perlakuan D memiliki rata-rata berat basah paling tinggi dibandingkan dengan perlakuan yang lainnya.

Perlakuan dengan penambahan kompos ampas tahu dengan komposisi paling banyak memiliki rata-rata berat basah yang paling tinggi. Hal ini disebabkan karena unsur hara yang diberikan mencukupi kebutuhan tanaman pak choi untuk tumbuh dengan baik. Hal ini sesuai dengan pernyataan Kubo (1993) bahwa produk ampas kedelai yang telah di fermentasi oleh mikroorganisme dapat menjadi pupuk yang efektif bagi tanaman. Unsur hara yang dapat mendukung tanaman pak choi untuk tumbuh dengan baik salah satunya yaitu unsur hara makro (NPK) dimana unsur ini dibutuhkan dalam jumlah yang banyak. Sehingga dengan komposisi $\mathrm{N}$, $\mathrm{P}$ dan $\mathrm{K}$ yang paling banyak pada penelitian ini akan lebih mendukung pertumbuhan pak choi untuk tumbuh dengan baik karena unsur $\mathrm{N}$ merangsang pertumbuhan secara keseluruhan khususnya akar, batang dan daun. Selain itu, unsur $\mathrm{N}$ ini berperan dalam membantu proses pembentukan klorofil yang berguna dalam proses fotosintesis. Proses fotosintesis yang terjadi menghasilkan nutrisi bagi tanaman. Semakin banyak unsur $\mathrm{N}$ yang terkandung dalam media tanam maka semakin banyak pula klorofil yang dibentuk untuk proses fotosintesis sehingga menyebabkan semakin banyak pula nutrisi yang tersedia bagi pertumbuhan tanaman.

Unsur $\mathrm{P}$ berperan untuk merangsang pertumbuhan akar. Pertumbuhan akar yang semakin cepat dan banyak dapat meningkatkan penyerapan air dan unsur hara. Semakin dalam atau jauh akar menembus tanah maka akan semakin banyak air dan unsur hara yang dapat diserap. Pengaruh unsur $\mathrm{K}$ berperan dalam memperkuat tubuh tanaman agar daun tidak mudah gugur.

Ketersediaan unsur $\mathrm{K}$ yang banyak dapat membuat tanaman lebih kokoh dan mempertahankan tubuhnya dari penyakit ataupun kekeringan. Berat basah tanaman menunjukkan besarnya kandungan air dan bahan organik yang terkandung dalam jaringan atau organ tanaman. Menurut Kaderi (dalam Puspitasari, 2013) pemberian bahan organik seperti kompos dapat membantu akar tanaman menembus tanah lebih dalam dan luas sehingga tanaman lebih mampu menyerap unsur hara dan air dalam jumlah banyak. Semakin banyak unsur hara dan air yang diserap oleh tanaman, akan meningkatkan pertumbuhan tanaman yang akan mempengaruhi ukuran organ tanaman secara keseluruhan. Sesuai dengan pernyataan sebelumnya bahwa unsur hara yang terdapat pada kompos limbah ampas tahu mempengaruhi pertambahan jumlah daun. Adanya pertambahan jumlah daun yang meningkat dapat mempengaruhi berat basah tanaman pak choi. Hal ini sesuai dengan yang diungkapkan oleh Pakaya (2015) bahwa bertambahnya jumlah daun dapat meningkatkan berat basah tanaman.

Perlakuan $\mathrm{N}$ memiliki rata-rata berat basah yang lebih rendah dibandingkan dengan perlakuan lainnya. Hal ini diakibatkan berkurangnya unsur hara yang terdapat pada media tanam. Menurut Campbell (2004: 340) menyatakan bahwa kekurangan unsur hara dapat melemahkan atau bahkan mematikan tumbuhan. Perlakuan unsur $\mathrm{N}$ ini mengalami kekurangan unsur hara dikarenakan tidak adanya penambahan unsur hara dari sumber lain hanya memanfaatkan unsur hara yang terkandung didalam tanah saja. Sehingga menyebabkan daun yang lebih tua mati karena kekurangan unsur hara.

Unsur hara yang tersedia akibat penambahan kompos limbah ampas tahu antara lain unsur nitrogen $(\mathrm{N})$, fosfor $(\mathrm{P})$, dan kalium $(\mathrm{K})$. Kandungan unsur $\mathrm{N}$ yang terdapat pada limbah ampas tahu berada pada kriteria rendah. Meskipun memiliki kriteria yang rendah namun keberadaan unsur $\mathrm{N}$ ini mampu mempengaruhi pertumbuhan tanaman pak choi. Menurut Sutedjo (2010: 89), unsur $\mathrm{N}$ berfungsi meningkatkan pertumbuhan tanaman, menyehatkan klorofil, meningkatkan kadar protein dalam tumbuhan, 
meningkatkan kualitas tanaman yang menghasilkan daun. Ketersediaan nitrogen yang cukup dan dalam keadaan seimbang dengan unsur lain dapat meningkatkan pertumbuhan vegetatif tanaman. Walaupun kriteria unsur $\mathrm{N}$ rendah namun kecukupan unsur hara $\mathrm{N}$ dibantu oleh adanya penambahan pupuk kandang.

Kandungan unsur $\mathrm{P}$ yang terdapat pada limbah ampas tahu memiliki kriteria sangat tinggi. Keberadaan unsur $\mathrm{P}$ dapat membantu proses asimilasi. Menurut Mehlich dan Drake (dalam Sutedjo,2010: 87) Unsur P merupakan bahan pembentuk inti sel, berperan penting dalam pembelahan sel serta perkembangan jaringan meristematik sehingga berpengaruh untuk pembentukan bakal daun dan memperluas ukuran daun.

Kandungan unsur $\mathrm{K}$ yang terdapat dalam limbah ampas tahu memiliki kriteria yang sangat tinggi. Keberadaan unsur $\mathrm{K}$ ini dapat mengatur proses fisiologi tumbuhan. Kegunaan unsur $\mathrm{K}$ pada tanaman adalah membantu membuat protein dan karbohidrat, memperkuat jaringan tanaman, serta membantu antibodi tanaman melawan penyakit dan kekeringan. Selain itu, untuk mengatur berbagai proses fisiologi tanaman. Kalium merupakan pengaktif dari sejumlah besar enzim yang penting untuk fotosintesis dan respirasi (Salisbury, 1995:145).

Unsur NPK dibutuhkan dalam jumlah yang besar dibandingkan dengan kebutuhan pada unsur lainnya. Sehingga banyak sedikitnya unsur hara yang terdapat pada media tanam mempengaruhi pertumbuhan tanaman.

\section{SIMPULAN}

1. Pemberian Limbah Ampas Tahu berpengaruh nyata terhadap pertambahan jumlah daun dan berat basah tanaman pak choi.

2. Pertumbuhan tanaman pak choi (Brassica rapa L. ssp Chinensis) pada perlakuan D dengan komposisi $100 \%$ limbah ampas tahu menunjukan peningkatan yang optimal dilihat dari parameter jumlah daun dan berat basah dibandingkan perlakuan yang lainnya.

3. Komposisi kandungan unsur Nitrogen $(\mathrm{N})$, Fosfor (P), dan Kalium (K) yang terdapat dalam limbah ampas tahu yaitu unsur $\mathrm{N}$ sebesar $0,110 \%$ berada pada kriteria rendah, unsur $\mathrm{P}$ sebesar 1,219\% dan unsur $\mathrm{K}$ sebesar $0,361 \%$ memiliki kriteria sangat tinggi.

\section{REFERENSI}

Agustina, Lilis. 2015. Bioentrepreneurship. Makalah Inovasi Pembelajaran Biologi. Program Studi Pendidikan Bilologi. Fakultas Ilmu Tarbiyah dan Keguruan, Institut Agama Islam Negeri Syekh Nurjati Cirebon, Cirebon. (Online). www.academia.edu. Diakses 14 Februari 2016

Ali, Farida. Muhammad E. dan A. Karisma. 2008. Pembuatan Kompos Dari Ampas Tahu Dengan Activator Stardec (Online). Jurnal Teknik Kimia. Volume 15, Nomor 3. http://jtk.unsri.ac.id. Diakses 5 januari 2016

Asmoro, Yuliadi., Suranto dan D.Sutoyo. 2008. Pemanfaatan Limbah Tahu Untuk Peningkatan Hasil Tanaman Petsai (Brassica chinensis) (Online). Jurnal Bioteknologi. Volume 5, nomor 2. Halaman 51-55. http://biosains.mipa.uns.ac.id. Diakses 5 Januari 2016

Campbell, Neil.A, Jane B. Reece and Lawrence G. Mitchell. 2004. Biologi Edisi Kelima Jilid II. Jakarta : Erlngga

Harahap, Ardian D., Tengku Nurhidayah, dan Sukemi Indra S. 2015. Pengaruh Pemberian Kompos Ampas Tahu Terhadap Pertumbuhan Bibit Kopi Robusta (Coffea canephora pierre) Dibawah Naungan Tanaman Kelapa Sawit (Online). Jurnal Agroteknologi. Volume 2, nomor 1. http://jom.unri.ac.id. Diakses 5 Januari 2016

Kubo, Motoki., J. Okajima and F. Hasumi. 1993. Isolation and Characterization of Soybean Waste-Degrading Microorganisms and Analysis of Fertilizer Effects of the Degraded Products. Dept. Of Chemistry and Biochemistry, Numazu College of Technology, Ooka, Numazu, Shizuoka and Dept. Of Bioengineering, Tokyo Institute of Technology, Japan (Online). Jurnal. Volume 60, Nomor 1. Halaman 243-247.

http://www.ncbi.nlm.nih.gov/pmc/article s/PMC201295. Diakses 28 Juni 2016

Maryam, Anita. 2009. Pengaruh Jenis Pupuk Organik Terhadap Pertumbuhan Dan Hasil Panen Tanaman Sayuran Di Dalam Nethouse (Online). Skripsi. Fakultas Pertanian, Institut Pertanian Bogor, 
Quagga: Jurnal Pendidikan dan Biologi

Volume 9, Nomor 2, Juli 2017

Bogor. $\quad$ http://repository.ipb.ac.id. Diakses: 13 Februari 2016

Nurhayati, Nunung., Musa Hubeis dan S. Raharja. 2011. Kelayakan dan Strategi Pengembangan Usaha Industri Kecil Tahu Di Kabupaten Kuningan, Jawa Barat (Online). Jurnal Manajemen. Volume 7, Nomor 2. Halaman 111-121. http://journal.ipb.ac.id. Diakses 10 Februari 2016

Pakaya, Jefri S., Mohamad Ikbal B. Dan Marleni L. 2015. Respon Pertumbuhan Dan Hasil Tanaman Sawi Hijau (Brassica juncea L.) Berdasarkan Penggunaan Mulsa Plastik Dan Dosis Pupuk Urea (Online). Jurnal Agroteknologi. Volume 3, Nomor 3. http://kim.ung.ac.id. Diakses 6 Juni 2016

Puspita, S., Riza Linda dan Mukarlina. 2013. Pertumbuhan Tanaman Pak Choy (Brassica chinensis L.) dengan Pemberian Kompos Alang - Alang (Imperata cylindrica (L.) Beauv) Pada Tanah Gambut (Online). Jurnal Protobiont. Volume 2, Nomor 2. Halaman 44-48. http://jurnal.untan.ac.id. Diakses 6 Juni 2016

Rubatzky, Vincent E. dan Mas yamaguchi. 1998. Sayuran Dunia 2 : Prinsip, Produksi, dan Gizi. ITB, Bandung

Salisbury, Frank. B. Dan Cleon W. Ross. 1995. Fisiologi Tumbuhan Jilid 1. Penerbit ITB, Bandung

Surtinah. 2013. Pengujian Kandungan Unsur Hara Dalam Kompos Yang Berasal Dari Serasah Tanaman Jagung Manis (Zea mays saccharata) (Online). Jurnal Ilmiah Pertanian. Volume 11, Nomor 1. http://unilak.ac.id. Diakses 15 juni 2016

Suswardany, D. L., Ambarwati dan Y. Kusumawati. 2006. Peranan Efektive Microorganisme-4 (EM-4) Dalam Meningkatkan Kualitas Kimia Kompos Ampas Tahu (Online). Jurnal Kesehatan Masyarakat. Volume 7, nomor 2. https://publikasiilmiah.ums.ac.id.

Diakses 2 Februari 2016

Sutedjo, Ir. Mul Mulyani dan Ir. A.G. Kartasapoetra. 2010. Pengantar Ilmu Tanah Terbentuknya Tanah dan Tanah Pertanian. PT Rineka Cipta, Jakarta

Suwahyono,Untung dan Tim Penulis PS. 2015. Cara Cepat Buat Kompos Dari Limbah. Penebar Swadaya, Jakarta
p-ISSN 1907-3089, e-ISSN 2651-5869

https://journal.uniku.ac.id/index.php/quagga

Tua, R., Sampoerno dan E. Anom. 2014. Pemberian Kompos Ampas Tahu Dan Urine Sapi Pada Pertumbuhan Bibit Kelapa Sawit (Elaeis guineensis Jacq) (Online). Jurnal Agroteknologi. Volume 1, nomor 1. http://jom.unri.ac.id. Diakses: 2 Februari 2016

Yuwono, Dipo. 2006. Kompos. Penebar Swadaya, Jakarta 